\title{
ASSESSMENT OF POSSIBILITIES OF STRAWBERRY JAM REFORMULATION
}

\author{
Ladislava Rýdlová, Tereza Škorpilová, Gabriela Juhászová, Aleš Rajchl
}

\begin{abstract}
The prevalence of excessive weight gain, obesity, and associated diseases are permanently increasing. Therefore, the interest in food products with a composition suitable for people with the aforementioned health problems is also on the rise. The changes in food composition, nowadays often called reformulation, are mainly focused on reducing the amount of salt, sugar, or fat. Strawberry spreads with different sugar $(10-40 \%)$ and strawberry $(20-50 \%)$ content were prepared and the influence of strawberry jam composition on gel stiffness, colour, and sensory parameters was studied. This study aimed to determine the sensorial and technological limits (sugar and strawberry content) of strawberry jam reformulation. Carrageenan was chosen as a suitable gelling agent for the preparation of these reformulated strawberry products. strawberry spreads. The applicable concentration of carrageenan for the ideal stiffness of strawberry spreads was $2 \%$. The results of the maximum compression force show a statistically significant increase of gel stiffness with increasing addition of strawberry puree, the effect of sugar content was also statistically significant $(p=0.05)$. This study showed that strawberry spreads with low strawberry and/or sugar content are sensorially acceptable.
\end{abstract}

Keywords: fruit spreads; carrageenan; texture characteristics; colour

\section{INTRODUCTION}

At the end of 2011, the world population had reached 7 billion and it is supposed the increase of one billion people to 2025. Around one billion people in the 21st century are starving and another billion people are suffering from micronutrient deficiency. On the other hand,

a billion people worldwide are deemed overweight or obese, with increased risk of associated diseases. Even with sufficient intake or excessive energy, consumed food can remain a poor source of essential nutrients. Opportunities to improve the nutritional profile and sustainability of the diet are found throughout the food chain, farm production, retail, and households. These include crop diversification, food enrichment, improvements in the efficiency of transport, waste minimisation, and last but not least food reformulation (Buttriss, 2013).

The food industry has two main approaches to product reformulation: gradual reduction of nutrient content without introducing further changes in product formulation or partial/total replacement with other nutrients such as hydrocolloids, fat substitutes, and sweeteners (Ares et al., 2018). However, some studies have found that products without added salt or sugars leave a negative sensory impression (Phelps et al., 2006; DuBois and Prakash, 2012). Added sugars are defined as sugars that are added to foods during processing, preparation, or "on the table". They contribute to the energy value of the diet but have a little nutritional benefit and their high intake is associated with increased dietary energy, dental caries, and other adverse health effects such as excessive weight gain and reduced bone density. The current $\mathrm{WHO}$ recommendation is that the intake of added sugars should be less than $10 \%$ of the total energy intake (WHO, 2015; Yeung et al., 2017). Replacing sugars in reformulated foods could represent a strategy to reduce sugar intake in the population without a significant change in the normal diet. However, reducing the sugar content of food is not easy because it results in changes to taste, texture, functionality and shelf life (van Raaij, Hendriksen and Verhagen, 2009; Cruz et al., 2010). The hygroscopic nature of sugar plays an important role in reducing water activity in foods and helps maintain and prolong the shelf life of foods. Sugar prevents for example microbial spoilage of jams after opening. It is therefore always necessary to understand the function of sucrose in a particular food product before it is replaced (Goldfein and Slavin, 2015).

Fruit, vegetables, and related products are often perceived by the consumer as "healthy" and consumable in any quantity. However, fruit and in particular for fruit products should be consumed with caution. Fruit products (compotes, fruit spreads, candied fruit, and other) often contain high sugar content. The effort to reformulate is then significant for the aforementioned reasons (Rýdlová et al., 2019). The term "fruit spreads" is generally used in the food processing industry for marmalades, jams, jellies, and similar products. Fruit spreads have traditionally high 
sugar content $(60-65 \%)$, and there is the possibility for their reformulation. The formation of the desired jelly consistency of a fruit spread with reduced sugar content can be achieved by the use of low-esterified pectins or alternatively gelling agents based on gums or extracellular products of microorganisms (Kadlec, Melzoch and Voldřich, 2012).

\section{Scientific hypothesis}

It is possible to reduce sugar content (up to $10 \%$ ) and/or strawberry content (up to $20 \%$ ) of the strawberry jam without it will result in less acceptable products.

There are technological and sensory acceptance limits for the sugar and/or strawberry content in strawberry spreads.

\section{MATERIAL AND METHODOLOGY}

Carrageenan C (CEAMGEL 9205; CEAMSA, Spain), citric acid (Hubka-Petrášek a vnuci s.r.o., Czech Republic), sucrose (DIAMANT; 1. Cukerní společnost Praha, s.r.o., Czech Republic), strawberry puree (100\%) (Fruta Podivín, a.s., Hamé s.r.o., Czech Republic), distilled water, potassium hydrogen phthalate (SIGMA-ALDRICH, USA).

\section{Sample preparation}

Carrageenan gels $(n=2) .36$ samples of carrageenan gels $(\mathrm{C} 1-\mathrm{C} 36$, Table 1$)$ with different sugar $(10 \%, 20 \%$, $30 \%$ and $40 \%)$, citric acid $(0 \%, 0.25 \%$ and $0.5 \%)$ and carrageenan $(1 \%, 1.5 \%$ and $2 \%)$ content were prepared. The calculated amount of sugar and carrageenan was added to boiling water in a multifunctional blender (Thermomix TM31, VORWERK, France), and the batch was agitated at $80{ }^{\circ} \mathrm{C}$ for 15 minutes. After 13 minutes of agitation, the calculated amount of citric acid was added (as a $50 \%$ water solution). The preparation of samples was carried out in the closed cooking blender. The total mass of one batch was $500 \mathrm{~g}$. From each batch, 10 identical samples were prepared in $25 \mathrm{~mL}$ beakers. The cooked samples were stored in a refrigerator at $10^{\circ} \mathrm{C}$ for 16 hours.

Strawberry spreads $(n=3) .16$ samples of strawberry spreads (J1 - J16, Table 2, Figure 1) with different content of strawberry puree $(20 \%, 30 \%, 40 \%$, and $50 \%)$ and sugar $(10 \%, 20 \%, 30 \%$, and $40 \%)$ were prepared. Samples were prepared in the same way as carrageenan gels except that the strawberry puree was used instead of boiling water and heat-treated in a mixer at $90{ }^{\circ} \mathrm{C}$ for $10 \mathrm{~min}$. The final mass of each batch was $500 \mathrm{~g}$.

\section{Methods}

Gel stiffness $(\mathrm{n}=10)$. Gel stiffness was analysed according to the method of Sinthusamran, Benjakul and Kishimura (2014) with a slight modification. The tests were performed with an Instron Model 5544 (Instron Ltd., USA). For the measurement, a $1-\mathrm{cm}$ wide cylindrical plunger with a straight tip was used. The plunger's movement velocity was $80 \mathrm{~mm} \cdot \mathrm{min}^{-1}$. The maximum force required to retract the plunger to a depth of $4 \mathrm{~mm}$ into the gel was recorded.

Titration acidity $(\mathrm{n}=3)$ was measured by titration with $0.1 \mathrm{M} \mathrm{NaOH}(\mathrm{pH} 8.1)$ and calculated as citric acid content
(DL-22 Food \& Beverage Analyzer, Mettler Toledo Co., Switzerland). Titration acidity was determined by (AOAC, 2002).

Colour $(\mathrm{n}=6)$. Colour determination was performed in the CIEL $\mathrm{a}^{*} \mathrm{~b} *$ ( $L *$ lightness, $a *$ redness, $b *$ yellowness) colour space on a Minolta CM-5 spectrophotometer (Konica Minolta, Osaka, Japan). The parameters $L^{*}, a^{*}$, and $b^{*}$ of strawberry spreads (J1 - J16) were determined (Igual, Contreras, and Martínez-Navarrete, 2014). Samples were always dispensed into a cylindrical glass cell up to a height of $3 \mathrm{~cm}$. The cell was placed on a measuring window with $30 \mathrm{~mm}$ diameters. Measurements were carried out in both the specular component included (SCI) mode and the specular component excluded (SCE) mode. The values measured in SCE mode were used for further processing in this study.

Soluble solid content $(n=3)$ of strawberry puree and strawberry spreads were measured using a digital refractometer (KRÜSS DR301-95, Germany).

Sensory analysis. The test room was equipped according to the requirements of the international standard (UNI ISO $\mathbf{8 5 8 9}, \mathbf{2 0 0 7}$ ). The strawberry spread samples were evaluated by untrained sensory panellists $(n=30)$. The strawberry spread samples were evaluated for texture, sweet taste, sour taste, fruity taste, and overall acceptability. Sensory attributes were recorded using a nine-point hedonic scale $(1=$ dislike extremely; $5=$ neither like nor dislike, $9=$ like extremely).

\section{Statistical analysis}

Outliers, identified according to a Dean-Dixon test, were excluded at the significance level of $p=0.05$. Results are presented as mean \pm standard deviation. Data obtained from texture analysis, colour measurement, and sensory analysis were analysed using the Student t-test. Statistical analyses were carried out using the Statistica 12.0 software (Statsoft Inc., Tulsa, OK, USA). All the measurements of titration acidity and soluble solids were performed in triplicate. The measurement of colour was performed in six replicates, and the measurement of gel stiffness was performed ten times for each sample.

\section{RESULTS AND DISCUSSION}

According to the literature review (Tang et al., 2019; Ellis et al., 2019; Ortiz-Tafoya et al., 2018), carrageenan was chosen as a gelling agent for reformulated strawberry jam. The model samples of carrageenan gel were prepared (Table 1), and gel stiffness was measured. The results of the carrageenan gel stiffness are shown in Figure 2, Figure 3 , and Figure 4. The results show that carrageenan, sugar, and citric acid content influence the gelling ability and gel stiffness of carrageenan gels. The gel stiffness increased significantly with increasing amounts of carrageenan. Likewise, the addition of sugar slightly increased the gel stiffness, as confirmed by the results of studies by LopezSanchez et al. (2018), Maurer, Junghans, and Vilgis (2012), Deszczynski, Kasapis and Mitchell (2003) and Watase et al. (1990). However, the addition of citric acid significantly reduces the gel stiffness of carrageenan gels $(p=0.05)$. 
Table 1 Recipes of carrageenan gels for evaluation of sugar and citric acid content on the gelling ability of carrageenan.

\begin{tabular}{|c|c|c|c|c|}
\hline \multirow{2}{*}{ Content of citric acid $=0 \%$} & & \multicolumn{3}{|c|}{ Content of carrageenan C [\%] } \\
\hline & & 1 & 1.5 & 2 \\
\hline \multirow{4}{*}{ Sugar content $[\%]$} & 10 & $\mathrm{C} 1$ & $\mathrm{C} 5$ & C9 \\
\hline & 20 & $\mathrm{C} 2$ & C6 & $\mathrm{C} 10$ \\
\hline & 30 & $\mathrm{C} 3$ & $\mathrm{C} 7$ & $\mathrm{C} 11$ \\
\hline & 40 & $\mathrm{C} 4$ & $\mathrm{C} 8$ & $\mathrm{C} 12$ \\
\hline \multirow{2}{*}{ Content of citric acid $=0.25 \%$} & & \multicolumn{3}{|c|}{ Content of carrageenan $\mathrm{C}[\%]$} \\
\hline & & 1 & 1.5 & 2 \\
\hline \multirow{4}{*}{ Sugar content $[\%]$} & 10 & $\mathrm{C} 13$ & $\mathrm{C} 17$ & $\mathrm{C} 21$ \\
\hline & 20 & $\mathrm{C} 14$ & $\mathrm{C} 18$ & $\mathrm{C} 22$ \\
\hline & 30 & $\mathrm{C} 15$ & $\mathrm{C} 19$ & $\mathrm{C} 23$ \\
\hline & 40 & $\mathrm{C} 16$ & $\mathrm{C} 20$ & $\mathrm{C} 24$ \\
\hline \multirow{2}{*}{ Content of citric acid $=\mathbf{0 . 5 \%}$} & & \multicolumn{3}{|c|}{ Content of carrageenan C [\%] } \\
\hline & & 1 & 1.5 & 2 \\
\hline \multirow{4}{*}{ Sugar content $[\%]$} & 10 & $\mathrm{C} 25$ & $\mathrm{C} 29$ & $\mathrm{C} 33$ \\
\hline & 20 & $\mathrm{C} 26$ & C30 & $\mathrm{C} 34$ \\
\hline & 30 & $\mathrm{C} 27$ & C31 & $\mathrm{C} 35$ \\
\hline & 40 & $\mathrm{C} 28$ & $\mathrm{C} 32$ & $\mathrm{C} 36$ \\
\hline
\end{tabular}

Table 2 Recipes of strawberry spreads with carrageenan as the gelling agent.

\begin{tabular}{|c|c|c|c|c|c|}
\hline \multirow{2}{*}{\multicolumn{2}{|c|}{ Content of carrageenan $\mathrm{C}=\mathbf{2 \%}$}} & \multicolumn{4}{|c|}{ Content of strawberry puree [\%] } \\
\hline & & 20 & 30 & 40 & 50 \\
\hline \multirow{4}{*}{ Sugar content $[\%]$} & 10 & $\mathrm{~J} 1$ & $\mathrm{~J} 5$ & J9 & $\mathrm{J} 13$ \\
\hline & 20 & $\mathrm{~J} 2$ & J6 & $\mathrm{J} 10$ & $\mathrm{~J} 14$ \\
\hline & 30 & $\mathrm{~J} 3$ & $\mathrm{~J} 7$ & $\mathrm{~J} 11$ & $\mathrm{~J} 15$ \\
\hline & 40 & $\mathrm{~J} 4$ & $\mathrm{~J} 8$ & $\mathrm{~J} 12$ & $\mathrm{~J} 16$ \\
\hline \multicolumn{2}{|c|}{ Addition of citric acid [\%] } & 0.32 & 0.23 & 0.14 & 0.05 \\
\hline
\end{tabular}

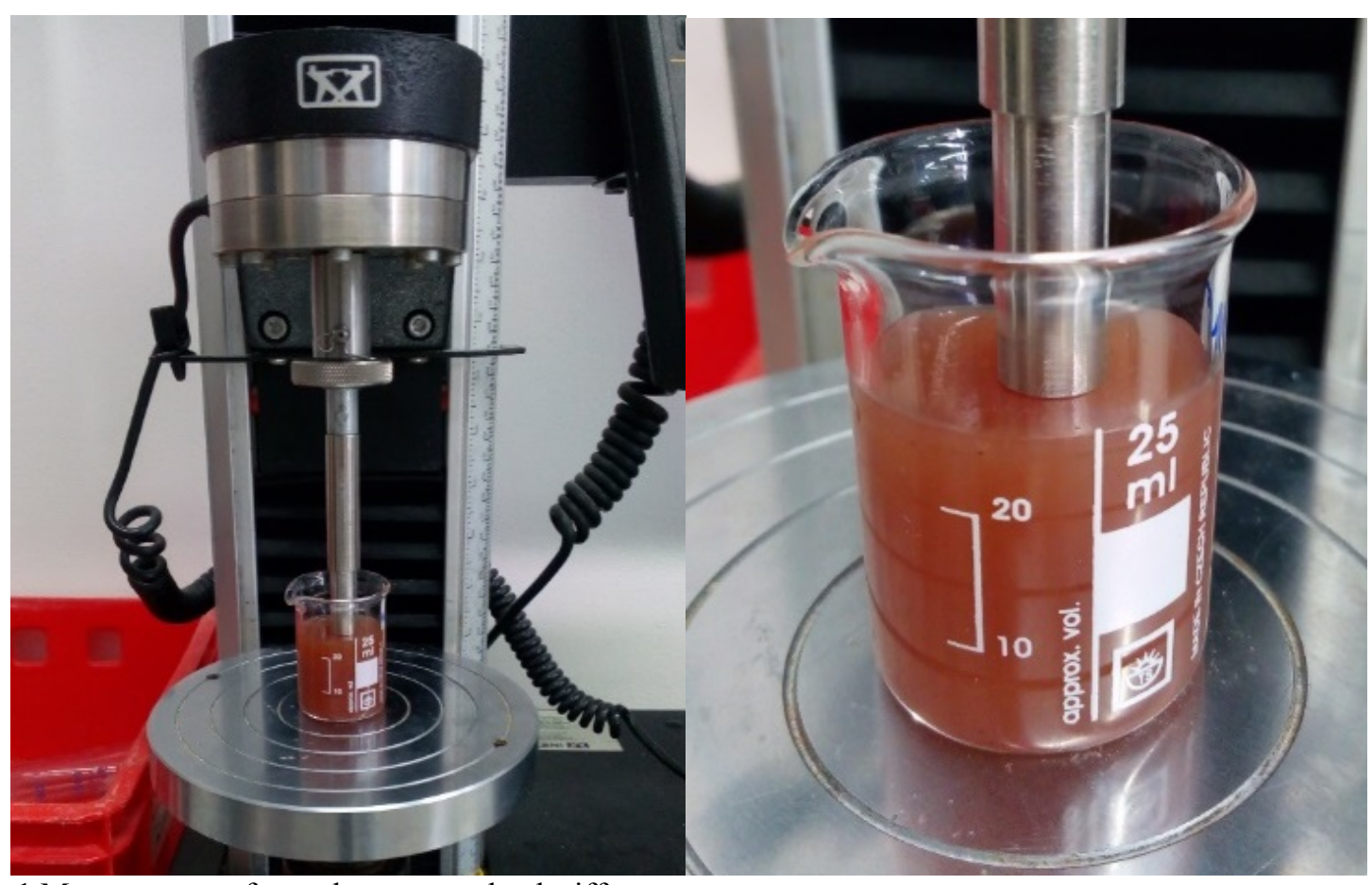

Figure 1 Measurement of strawberry spread gel stiffness. 


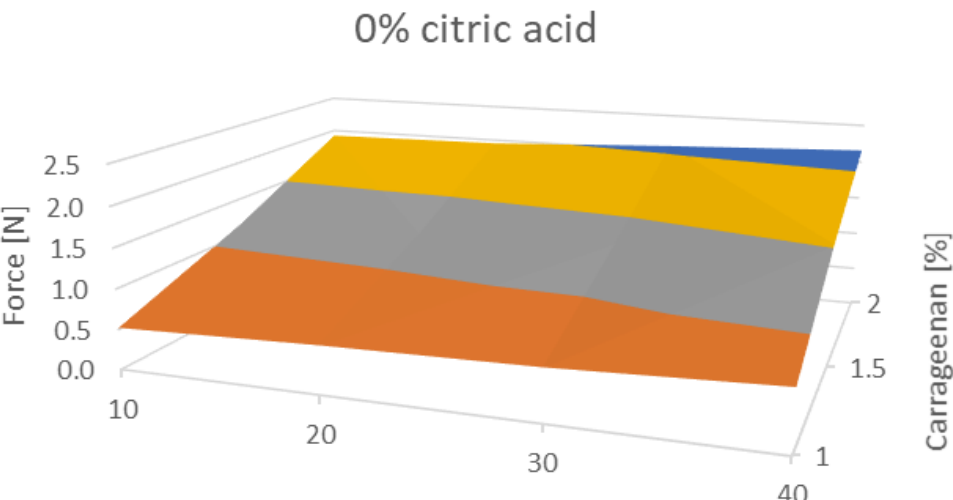

Sugar $[\%]$

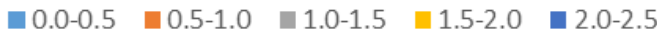

Figure 2 Dependence of gel stiffness on sugar and carrageenan C content, content of citric acid $=0.00 \%$.

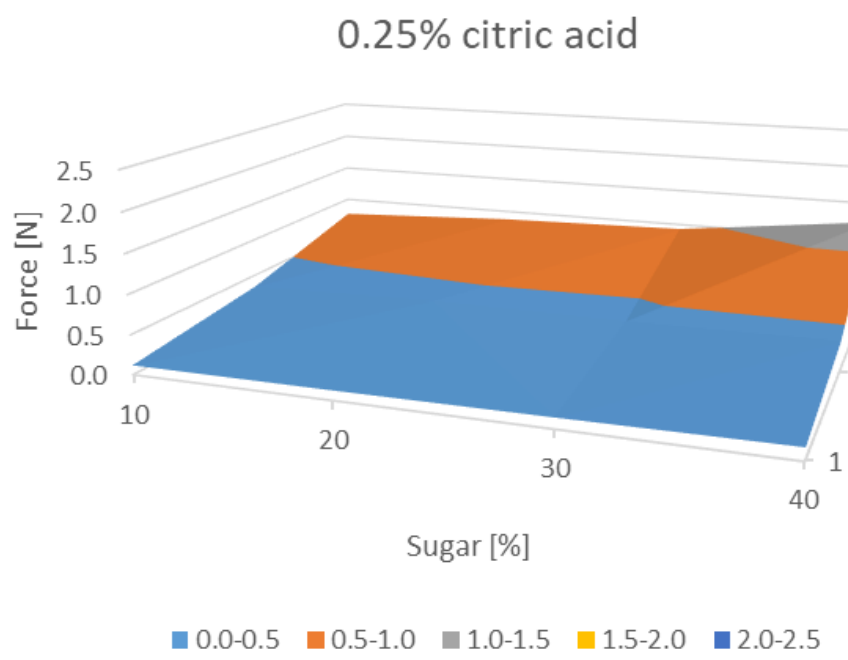

Figure 3 Dependence of gel stiffness on sugar and carrageenan $\mathrm{C}$ content, content of citric acid $=0.25 \%$.

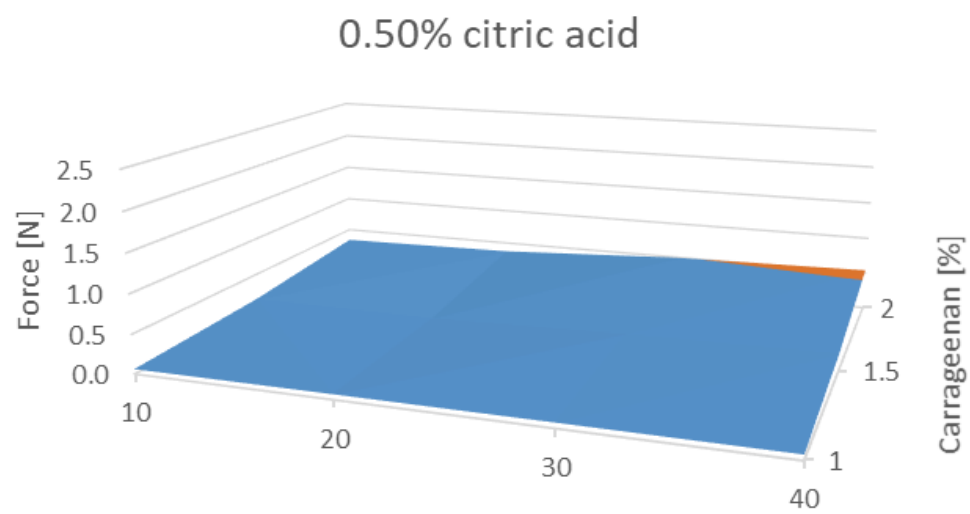

Sugar [\%]

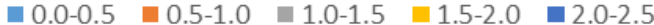

Figure 4 Dependence of gel stiffness on sugar and carrageenan $\mathrm{C}$ content, content of citric acid $=0.50 \%$. 

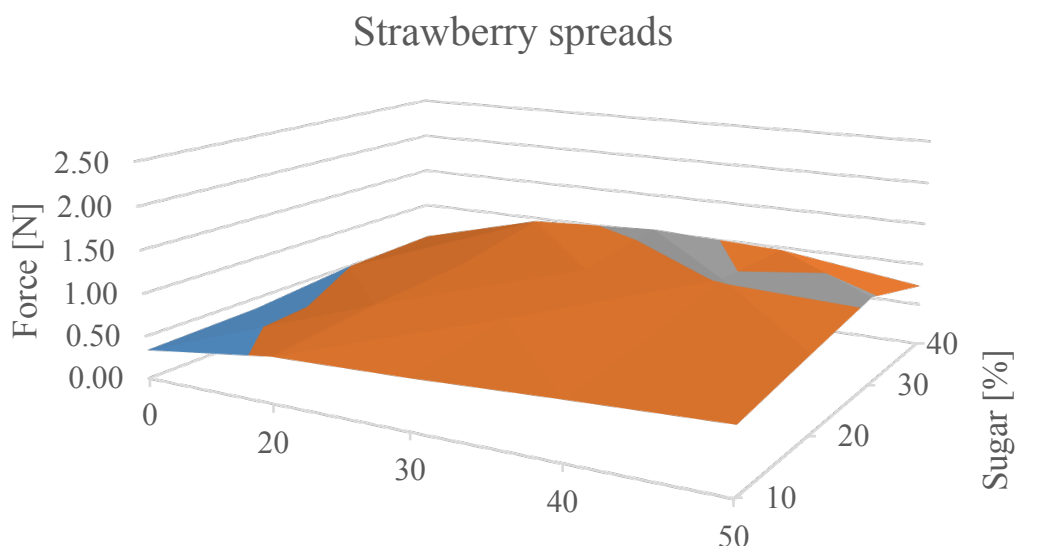

Strawberry puree[\%]

$$
\square 0.00-0.50 \quad \square 0.50-1.00 \quad \square 1.00-1.50 \quad \square 1.50-2.00 \quad \square 2.00-2.50
$$

Figure 5 Dependence of strawberry spread stiffness on the content of strawberry puree and sugar, addition of carrageenan $\mathrm{C}=2 \%$ and addition of citric acid to the total content of $0.50 \%$.

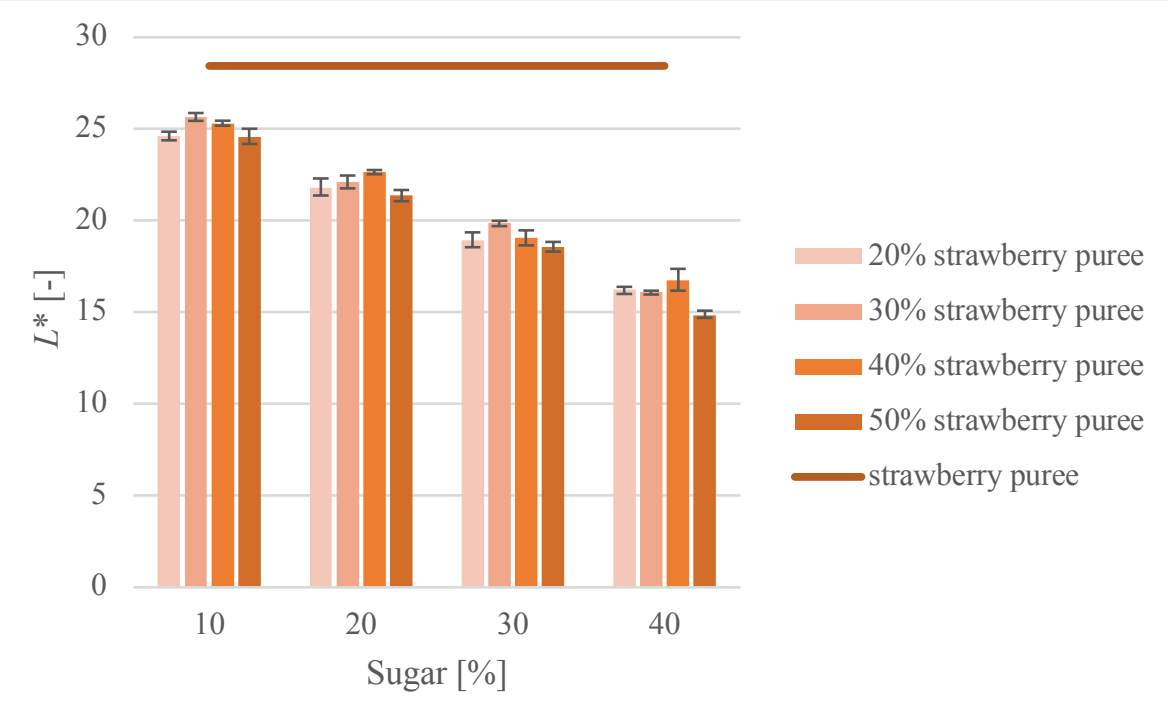

Figure 6 Dependence of $\mathrm{L}^{*}$ on sugar content and strawberry puree content in the samples $\mathrm{J} 1$ - J16 in comparison with strawberry puree.

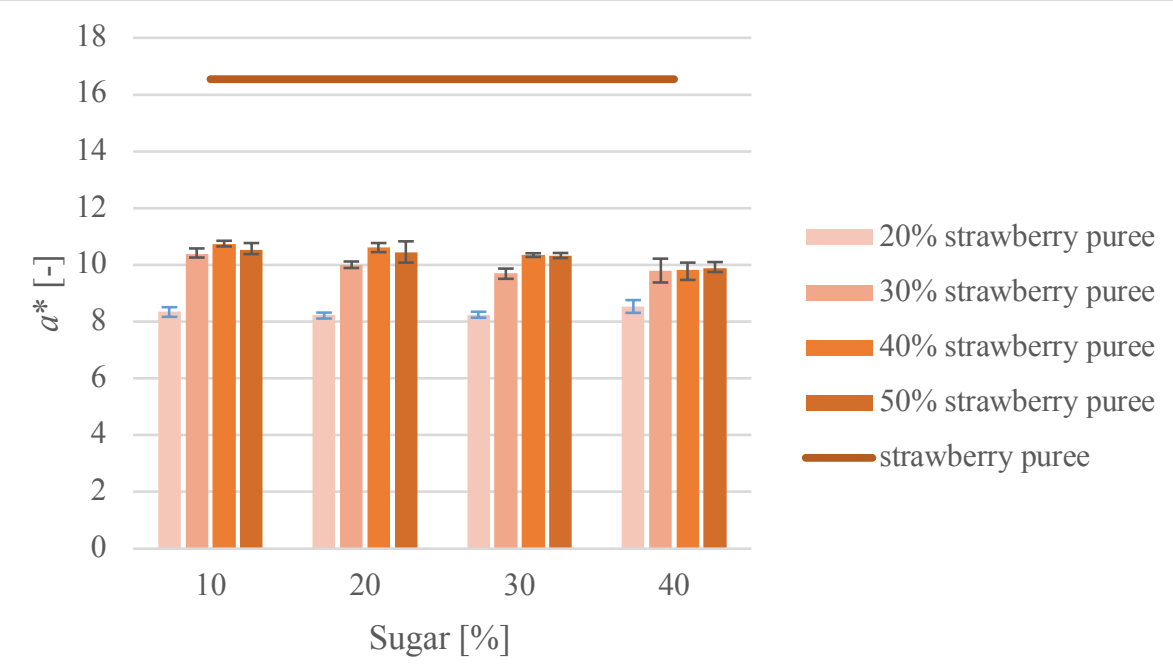

Figure 7 Dependence of $\mathrm{a}^{*}$ on sugar content and strawberry puree content in the samples J1 - J16 in comparison with strawberry puree. 


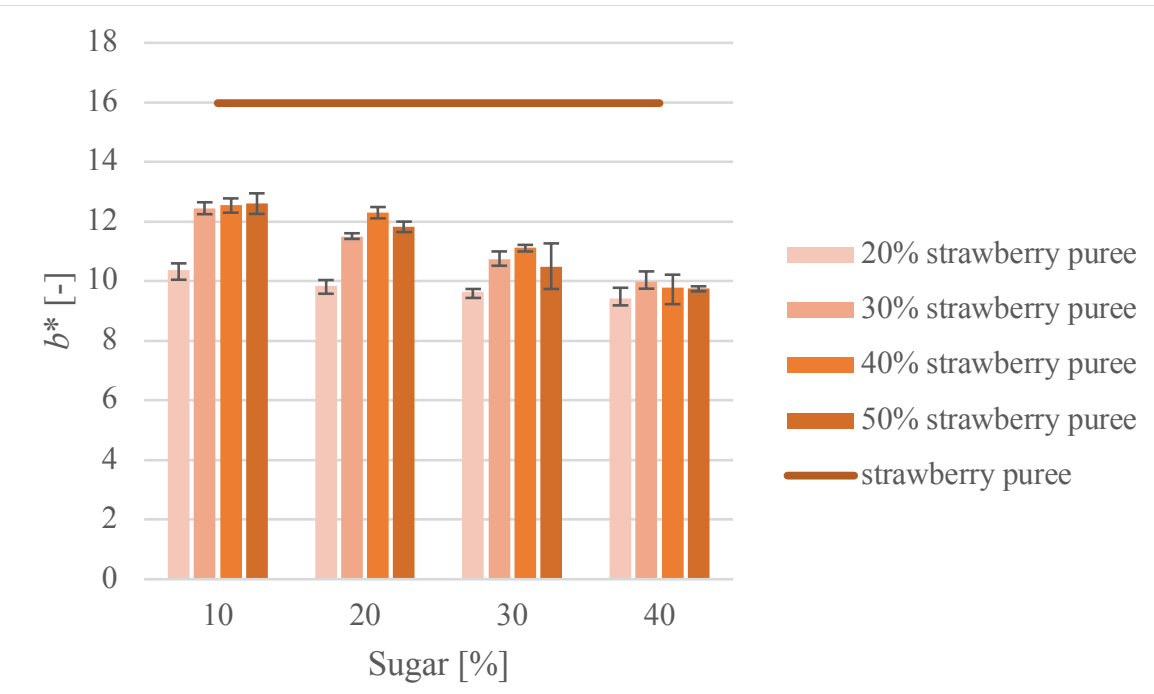

Figure 8 Dependence of $b^{*}$ on sugar content and strawberry puree content in the samples J1-J16 in comparison with strawberry puree.

Table 3 Sensory analysis results of the strawberry spread samples (J1 - J16).

\begin{tabular}{|c|c|c|c|c|c|}
\hline \multirow{2}{*}{ Sample } & \multicolumn{5}{|c|}{ Sensory attributes } \\
\hline & Texture & Sweet taste & Sour taste & Fruity taste & Overall acceptability \\
\hline $\mathbf{J 1}$ & $4.00 \pm 1.56^{b}$ & $3.70 \pm 1.77^{\mathrm{c}}$ & $3.20 \pm 1.99$ & $2.30 \pm 1.70^{\mathrm{a}}$ & $3.35 \pm 2.86$ \\
\hline $\mathbf{J} 2$ & $4.60 \pm 1.58^{\mathrm{a}}$ & $5.80 \pm 1.55^{b}$ & $3.60 \pm 2.12$ & $3.80 \pm 2.15$ & $4.87 \pm 2.65$ \\
\hline $\mathbf{J 3}$ & $5.40 \pm 1.96$ & $7.00 \pm 1.94^{\mathrm{c}}$ & $3.70 \pm 1.34$ & $4.00 \pm 1.56^{\mathrm{a}}$ & $4.92 \pm 2.56$ \\
\hline J4 & $5.50 \pm 1.27^{\mathrm{a}}$ & $7.70 \pm 1.49^{c}$ & $3.70 \pm 1.34$ & $4.00 \pm 1.49^{\mathrm{a}}$ & $4.20 \pm 2.83$ \\
\hline J5 & $4.50 \pm 1.51^{\mathrm{a}}$ & $4.00 \pm 1.70^{\mathrm{c}}$ & $3.20 \pm 2.15$ & $2.80 \pm 1.40$ & $4.00 \pm 3.03$ \\
\hline J6 & $4.90 \pm 1.60$ & $6.10 \pm 1.79^{b}$ & $3.60 \pm 1.43$ & $3.60 \pm 1.26$ & $4.95 \pm 2.60$ \\
\hline $\mathbf{J} 7$ & $5.80 \pm 2.20^{\mathrm{a}}$ & $6.90 \pm 1.85^{\mathrm{c}}$ & $3.00 \pm 1.56$ & $3.90 \pm 1.60^{\mathrm{a}}$ & $4.25 \pm 2.41$ \\
\hline J8 & $6.20 \pm 1.48^{b}$ & $7.60 \pm 1.58^{c}$ & $3.40 \pm 1.26$ & $3.90 \pm 1.45^{\mathrm{a}}$ & $4.51 \pm 2.37$ \\
\hline J9 & $4.30 \pm 1.77^{\mathrm{a}}$ & $4.90 \pm 1.29^{c}$ & $3.30 \pm 1.83$ & $3.20 \pm 1.23$ & $4.29 \pm 2.88$ \\
\hline $\mathbf{J 1 0}$ & $5.00 \pm 1.76$ & $6.00 \pm 1.49^{\mathrm{b}}$ & $2.50 \pm 1.35$ & $3.70 \pm 1.34$ & $4.60 \pm 2.41$ \\
\hline $\mathbf{J 1 1}$ & $6.10 \pm 2.18^{\mathrm{a}}$ & $6.80 \pm 2.20^{\mathrm{b}}$ & $2.60 \pm 1.51$ & $3.40 \pm 1.43$ & $3.82 \pm 2.62$ \\
\hline $\mathrm{J} 12$ & $6.00 \pm 1.76^{\mathrm{a}}$ & $7.50 \pm 1.96^{\mathrm{c}}$ & $2.50 \pm 1.51$ & $3.60 \pm 1.78$ & $4.05 \pm 2.82$ \\
\hline $\mathbf{J 1 3}$ & $4.70 \pm 1.83$ & $4.50 \pm 1.65^{\mathrm{c}}$ & $2.50 \pm 1.65$ & $3.00 \pm 1.83$ & $4.14 \pm 2.95$ \\
\hline J14 & $5.00 \pm 1.70$ & $5.90 \pm 2.38^{a}$ & $2.70 \pm 1.89$ & $3.30 \pm 2.26$ & $4.48 \pm 2.96$ \\
\hline$J 15$ & $6.20 \pm 2.39^{\mathrm{a}}$ & $7.50 \pm 1.78^{c}$ & $2.70 \pm 1.77$ & $3.30 \pm 1.77$ & $3.53 \pm 2.54$ \\
\hline J16 & $5.70 \pm 1.70^{\mathrm{a}}$ & $8.30 \pm 1.83^{\mathrm{c}}$ & $2.70 \pm 1.49$ & $3.60 \pm 1.78$ & $3.91 \pm 3.16$ \\
\hline
\end{tabular}

Note: ${ }^{a}$ Significant difference by Student's t-test $(p=0.05),{ }^{\mathrm{b}}$ Significant difference by Student's t-test $(p=0.01),{ }^{\mathrm{c}}$

Significant difference by Student's t-test $(p=0.001)$.

The results show that it is not necessary to add citric acid to strawberry spreads because of the natural occurrence of organic acids in a strawberry puree to improve the texture parameters (Kallio et al., 2000; Sturm, Koron and Stampar, 2003). However, the addition of citric acid is necessary for the sensory parameter of the final product (balance of sweet and sour taste). Therefore, the same final concentration of $0.5 \%$ of citric acid was chosen for the preparation of all strawberry spreads.

One of the parameters of the overall sensory perception of this type of product for the consumer is gel stiffness (Pérez-Herrera et al., 2020). The results of the strawberry spreads gel stiffness (Figure 5) show, that both, sugar and strawberry puree content contribute to this ability to form a gel $(p=0.05)$. The maximum force required to compress 
the gel was higher than that of carrageenan gels with the same sugar and citric acid addition $(p=0.05)$. Samples containing $40-50 \%$ of strawberry puree and $30-40 \%$ of sugar achieved the highest gel stiffness. Only samples without strawberry puree and low sugar content $(10-20 \%)$ showed low gel stiffness.

Colour is one of the most important parameters of strawberries and strawberry products for their final perception and attractiveness to consumers (Bursać Kovačević et al., 2015). Parameter $\left(L^{*}\right)$ of prepared strawberry spreads J1 - J16 is shown in Figure 6. The results show that the addition of sugar significantly reduces product lightness $(p=0.001)$. This fact is probably due to the amount of sugar, which contributes to the Maillard reaction (Li et al., 2020; Liao et al., 2020; Shen, Chen and Li, 2018; Basu, Shivhare and Singh, 2013). The addition of strawberry puree also had a significant effect on parameter $L^{*}$ of strawberry spreads $(p=0.05)$, but less than that of sugar.

The parameter $a^{*}$ (redness, Figure 7) was not affected by the amount of sugar added $(p=0.05)$. Significantly lower was the redness $\left(a^{*}\right)$ of the strawberry spreads with a strawberry puree content of $20 \%$. On the other hand, the addition of strawberry puree affected the colour parameter $a^{*}(p=0.05)$.

Colour parameter $b^{*}$ (yellowness, Figure 8) was lower for samples with a strawberry puree content of $20 \%$ $(p=0.05)$. Like the parameter $L^{*}$, parameter $b^{*}$ decreased with the addition of sugar. This difference is statistically significant $(p=0.05)$.

The results of the sensory analysis of strawberry spreads (J1 - J16) are shown in Table 3. It is visible, that the evaluation of all samples was very subjective. The results of sensory evaluation of texture and sweet taste show that panellists identify differences between samples. In contrast to this fact, the differences in acid taste and overall acceptability $(p=0.05)$ were not perceived between samples. The overall acceptability values ranged across the whole hedonic scale for all samples. No statistically significant differences between the overall acceptability value of tested samples were observed $(p=0.05)$.

\section{CONCLUSION}

The reduction of sugar content in strawberry spreads was carried out with a focus on people with special nutritional requirements, specifically suffering from obesity and type 2 diabetes. Carrageenan is a suitable gelling agent for the preparation of reformulated strawberry spreads. The applicable concentration of carrageenan $\mathrm{C}$ in strawberry spreads for the ideal stiffness of strawberry spreads was $2 \%$. The results of the maximum compression force show a statistically significant increase of gel stiffness $(p=0.05)$ with the increasing addition of strawberry puree. As the sugar content in the model increases, the maximum compression force values increase. This effect is also statistically significant $(p=0.05)$ but not as much as the effect of strawberry puree. It was possible to reduce the sugar content in strawberry spreads up to $10 \%$ with acceptable sensory perception. The production of this type of fruit spreads with standard characteristics is a complex task influenced by many factors, including the type of used gelling agent and characteristics of input raw material. These reformulated strawberry spreads may be an alternative to jams, which are not recommended because of their high sugar content, for people suffering from these diseases.

\section{REFERENCES}

AOAC. 2002. AOAC Official Method 942.15, 2002. Acidity (titratable) of fruit products. Gaitherburg: AOAC International. $2 \mathrm{p}$.

Ares, G., Aschemann-Witzel, J., Curutchet, M. R., Antúnez, L., Machín, L., Vidal, L., Giménez, A. 2018. Product reformulation in the context of nutritional warning labels: Exploration of consumer preferences towards food concepts in three food categories. Food Research International, vol. 107 , $\mathrm{p}$.

669-674.

https://doi.org/10.1016/j.foodres.2018.03.021

Basu, S., Shivhare, U. S., Singh, T. V. 2013. Effect of substitution of stevioside and sucralose on rheological, spectral, color and microstructural characteristic of mango jam. Journal of Food Engineering, vol. 114, no. 4, p. 465476. https://doi.org/10.1016/j.jfoodeng.2012.08.035

Bursać Kovačević, D., Putnik P., Dragović-Uzelac, V., Vahčić, N., Skendrović Babojelić, M., Levaja, B. 2015. Influences of organically and conventionally grown strawberry cultivars on anthocyanins content and color in purees and low-sugar jams. Food Chemistry, vol. 181, p. 94100. https://doi.org/10.1016/j.foodchem.2015.02.063

Buttriss, J. L. 2013. Food reformulation: the challenges to the food industry. Proceedings of the Nutrition Society, vol. 72, no. 1, p. 61-69. https://doi.org/10.1017/S0029665112002868

Cruz, A. G., Cadena, R. S., Walter, E. H. M., Mortazavian, A. M., Granato, D., Faria, J. A. F., Bolini, H. M. A. 2010. Sensory analysis: Relevance for prebiotic, probiotic, and synbiotic product development. Comprehensive Reviews in Food Science and Food Safety, vol. 9, no. 4, p. 358-373. https://doi.org/10.1111/j.1541-4337.2010.00115.x

Deszczynski, M., Kasapis, S., Mitchell, J. R. 2003. Rheological investigation of the structural properties and aging effects in the garose/co-solute mixture. Carbohydrate Polymers, vol. 53, no. 1, p. 85-93. https://doi.org/10.1016/S0144-8617(02)00327-2

DuBois, G. E., Prakash, I. 2012. Non-caloric sweeteners, sweetness modulators, and sweetener enhancers. Annual Review of Food Science and Technology, vol. 3, p. 353-380. https://doi.org/10.1146/annurev-food-022811-101236

Ellis, A. L., Mills, T. B., Norton, I. T., Norton-Welch, A. B. 2019. The hydrophobic modification of kappa carrageenan microgel particles for the stabilisation of foams. Journal of Colloid and Interface Science, vol. 538, p. 165-173. https://doi.org/10.1016/j.jcis.2018.11.091

Goldfein, K. R., Slavin, J. L. 2015. Why sugar is added to food: Food Science 101. Comprehensive Reviews in Food Science and Food Safety, vol. 14, no. 5, p. 644-656. https://doi.org/10.1111/1541-4337.12151

Igual, M., Contreras, C., Martínez-Navarrete, N. 2014. Colour and rheological properties of non-conventional grapefruit jams: Instrumental and sensory measurement. $L W T$ - Food Science and Technology, vol. 56, no. 1, p. 200-206. https://doi.org/10.1016/j.lwt.2013.10.038

Kadlec, P., Melzoch, K., Voldřich, M. 2012. Technologie potravin - Přehled tradičnich potravinářských výrob (Food technology - Overview of traditional food production). $1^{\text {st }}$ ed. Ostrava, Czech Republic : Key publishing, 569 p. (In Czech) ISBN 978-80-7418-145-0.

Kallio, H., Hakala, M., Pelkkikangas A. M., Lapveteläinen, A. 2000. Sugars and acids of strawberry varieties. European 
Food Research and Technology, vol. 212, p. 81-85. https://doi.org/10.1007/s002170000244

Li, L., Zhang, M., Chitrakar, B., Jiang, H. 2020. Effect of combined drying method on phytochemical components, antioxidant capacity and hydroscopicity of Huyou (Citrus changshanensis) fruit. LWT-Food Science and Technology, vol. 123, 7 p. https://doi.org/10.1016/j.1wt.2020.109102

Liao, H., Zhu, W., Zhong, K., Liu, Y. 2020. Evaluation of colour stability of clear red pitaya juice treated by thermosonication. LWT - Food Science and Technology, vol. 121, 35 p. https://doi.org/10.1016/j.lwt.2019.108997

Lopez-Sanchez, P., Fredriksson, N., Larsson, A., Altskär, A., Ström, A. 2018. High sugar content impacts microstructure, mechanics and release of calcium-alginate gels. Food Hydrocolloids, vol. 84, p. 26-33. https://doi.org/10.1016/j.foodhyd.2018.05.029

Maurer, S., Junghans, A., Vilgis, T. A. 2012. Impact of xanthan gum, sucrose and fructose on the viscoelastic properties of agarose hydrogels. Food Hydrocolloids, vol. 29, no. 2 , p.

298-307.

https://doi.org/10.1016/j.foodhyd.2012.03.002

Ortiz-Tafoya, M. C., Rolland-Sabaté, A., Garnier, C., Valadez-García, J., Tecante, A. 2018. Thermal, conformational and rheological properties of $\kappa$-carrageenansodium stearoyl lactylate gels and solutions. Carbohydrate Polymers, vol. 193, p. 289-297. https://doi.org/10.1016/j.carbpol.2018.04.002

Pérez-Herrera, A., Martínez-Gutiérrez, G. A., LeónMartínez, F. M., Sánchez-Medina, M. A. 2020. The effect of the presence of seeds on the nutraceutical, sensory and rheological properties of Physalis spp. Fruits jam: A comparative analysis. Food Chemistry, vol. 302, 7 p. https://doi.org/10.1016/j.foodchem.2019.125141

Phelps, T., Angus, F., Clegg, S., Kilcast, D., Narain, C., den Ridder, C. 2006. Sensory issues in salt reduction. Food Quality and Preference, vol. 17, no. 7-8, p. 633-634. https://doi.org/10.1016/j.foodqual.2006.01.007

Rýdlová, L., Hrubá, M., Ševčík, R., Rajchl, A. 2019. Reformulace potravin (Reformulation of fruit and vegetable products. Food reformulation). In Rajchl, A. Reformulace výrobků $\mathrm{z}$ ovoce a zeleniny. V Rajchl, A. Reformulace potravin - Hodnoceni možností reformulací hlavních potravináršśých komodit. $1^{\text {st }}$ ed. Praha, Czech republic : Potravinářská komora České republiky, p. 107-124. (In Czech) ISBN 978-80-88019-36-7.

Shen, Y., Chen, G., Li, Y. 2018. Bread characteristic and antioxidant activities of Maillard reaction products of white pan bread containing various sugars. LWT - Food Science and Technology, vol. 95, p. 308-315. https://doi.org/10.1016/j.lwt.2018.05.008

Sinthusamran, S., Benjakul, S., Kishimura, H. 2014. Characteristics and gel properties of gelatin from skin oh seabass (Lates calcarifer) as influenced by extraction conditions. Food Chemistry, vol. 152, p. 276-284. https://doi.org/10.1016/j.foodchem.2013.11.109

Sturm, K., Koron, D., Stampar, F. 2003. The composition of fruit of different strawberry varieties depending on maturity stage. Food Chemistry, vol. 83, no. 3, p. 417-422. https://doi.org/10.1016/S0308-8146(03)00124-9

Tang, M., Zhu, Y., Li, D., Adhikari, B., Wang, L. 2019. Rheological, thermal and microstructural properties of casein/ $\kappa$-carrageenan mixed systems. LWT - Food Science and Technology, vol. 113
https://doi.org/10.1016/j.lwt.2019.108296

UNI ISO 8589. 2017. Sensory analysis - General guidance for the design of test rooms.

van Raaij, J., Hendriksen, M., Verhagen, H. 2009. Potential for improvement of population diet through reformulation of commonly eaten foods. Public Health Nutrition, vol. 12, no. 3, p. 325-330. https://doi.org/10.1017/S1368980008003376

Watase, M., Nishinari, K., Williams, P. A., Phillips, G. O. 1990. Agarose gels: Effect of sucrose, glucose, urea and guanidine hydrochloride on the rheological and thermal properties. Journal of Agricultural and Food Chemistry, vol. 38, no. 5, p. 1181-1187. https://doi.org/10.1021/jf00095a005

WHO. 2015. World Health Organisation: Information note about intake of sugars recommended in the WHO guideline for adults and children, 1st ed., WHO Document Production Services: Geneva, Switzerland. 49 p. ISBN 978-92-4-1549028.

Yeung, C. H. C., Gohil, P., Rangan, A. M., Flood, V. M., Arcot, J., Gill, T. P., Louie, J. C. Y. 2017. Modelling of the impact of universal added sugar reduction through food reformulation. Scientific Reports, vol. 7, no. 1,8 p. https://doi.org/10.1038/s41598-017-17417-8

\section{Acknowledgments:}

This study was supported by the project „Impact of reformulation on the shelf-life and physical and chemical properties of food products" (QK1910100) of the Ministry of Agriculture of the Czech Republic.

\section{Contact address:}

Ladislava Rýdlová, University of Chemistry and Technology Prague, Faculty of Food and Biochemical Technology, Department of Food Preservation, Technická, 3, 166 28, Prague 6 - Dejvice, Czech Republic, Tel.: +420220443024,

E-mail: rydloval@vscht.cz

ORCID: https://orcid.org/0000-0003-0597-9644

*Tereza Škorpilová, University of Chemistry and Technology Prague, Faculty of Food and Biochemical Technology, Department of Food Preservation, Technická, 3, 166 28, Prague 6 - Dejvice, Czech Republic, Tel.: +420220443003,

E-mail: skorpilt@,vscht.cz

ORCID: https://orcid.org/0000-0002-8796-6603

Gabriela Juhászová, University of Chemistry and Technology Prague, Faculty of Food and Biochemical Technology, Department of Food Preservation, Technická, 3, 166 28, Prague 6 - Dejvice, Czech Republic, Tel.: +420220443024,

E-mail: gabriela@juhaszova.cz

ORCID: https://orcid.org/0000-0002-6465-6143

Aleš Rajchl, University of Chemistry and Technology Prague, Faculty of Food and Biochemical Technology, Department of Food Preservation, Technická, 3, 166 28, Prague 6 - Dejvice, Czech Republic, Tel.: +420220443012,

E-mail: rajchla@vscht.cz

ORCID: https://orcid.org/0000-0002-4888-8323

Corresponding author: * 